\title{
DIREITO AO MEIO AMBIENTE ECOLOGICAMENTE EQUILIBRADO E À PROPRIEDADE PRIVADA: A EXIGIBILIDADE DE RESERVA FLORESTAL LEGAL EM ÁREA URBANA E DE EXPANSÃO URBANA
}

\author{
THE RIGHT TO AN ECOLOGICALLY BALANCED ENVIRONMENT AND THE \\ RIGHT TO PRIVATE PROPERTY: EXIBILITY OF FOREST RESERVE LEGAL IN \\ URBAN AREA AND URBAN SPRAWL
}

\author{
${ }^{1}$ Lais Batista Guerra \\ ${ }^{2}$ Rayanny Silva Siqueira Monteiro
}

\section{RESUMO}

Para assegurar a efetividade do direito ao meio ambiente ecologicamente equilibrado o Estado deve adotar certas medidas interventivas em detrimento de alguns direitos fundamentais, dentre os quais o direito de propriedade. Dentre essas limitações administrativas destaca-se a Reserva Florestal Legal - RFL, prevista na Lei 12.651/12 como uma área de uso restrito localizada no interior do todo imóvel rural, visando garantir o uso sustentável dos recursos naturais ali inseridos. Neste contexto, o presente trabalho objetiva abordar a exigibilidade de Reserva Florestal Legal em área urbana e de expansão urbana. Através da pesquisa exploratória e bibiográfica-documental, com método indutivo e qualitativo, examinou-se o direito ao meio ambiente sadio, o direito à propriedade e sua função socioambiental, os critérios de diferenciação da propriedade rural e urbana, questões sobre o parcelamento do solo urbano, bem como o próprio instituto de RFL para, por fim, abordar os contornos históricosociais e jurídicos da exibilidade da RFL na área urbana ou de expansão urbana, concluindose que, após a edição no novel Código Florestal não mais persistem obscuridades acerca da possibilidade do Poder Público exigir a manutenção da RFL em imóveis situados em áreas urbanas ou de expansão urbana definidas em lei, se estes mantiverem a finalidade rural.

Palavras-chave: Direito ao meio ambiente equilibrado, Direito à propriedade privada, Reserva florestal legal, Parcelamento do solo, Área urbana e de expansão urbana

\footnotetext{
${ }^{1}$ Mestranda em Direito Ambiental pela Universidade do Estado do Amazonas - UEA, Amazonas (Brasil). Procuradora pela Procuradoria Geral da Fazenda Nacional - PGFN, São Paulo (Brasil).

E-mail: laisguerra100@ hotmail.com

${ }^{2}$ Mestranda em Direito Ambiental pela Universidade do Estado do Amazonas - UEA, Amazonas (Brasil). E-mail: nanysiqueira@hotmail.com
} 


\begin{abstract}
To assure effectiveness of the right to an ecologically balanced environment the State must adopt certain measures opposite to some fundamental rights, among which the right to property. Among these administrative limitations, the Legal Forest Reserve LFR stands out, it has legal support in Law 12.651/12, as an area of restrictive use located within every rural real estate that intends to ensure the usage of the sustained resources inserted in the area. In this context, the present article aims to approach the requiring of Legal Forest Reserve in urban area and urban sprawl. Through exploratory, bibliographical-documental research, applying inductive and qualitative method, we examined the right to a healthy environment and to property, the socio-environmental function of the property, the criteria to differ rural from urban property, matters of urban land divisions and the LFR institute itself so that at last, we could approach the social, historic and legal outlines of the demanding of the LFR in the urban area and urban sprawl, concluding that after the edition of the new Forest Code there are no longer obscurities about the possibility for the Government to demand the LFR in real states located in urban areas or urban sprawls defined by law, as long as they maintain rural function.
\end{abstract}

KEYWORDS: Right to a balanced environment, Right to private property, Legal forest reserve, Land division, Urban area and urban sprawl 


\section{Introdução}

Para se assegurar a consecução do meio ambiente equilibrado, garantia constitucional e diametralmente ligada ao exercício da vida digna, inevitável a adoção de medidas interventivas por parte do Estado frente a certos direitos individuais, dentre eles o direito à propriedade.

Entremeado a estas limitações com vistas à conservação ambiental, destaca-se o instituto da Reserva Florestal Legal, previsto pelo Código Florestal como obrigatório a todos os imóveis rurais. É sob essa premissa que se insere o objeto de estudo do presente artigo: a exigibilidade da Reserva Florestal Legal em áreas urbanas ou de expansão urbana.

Para o desenvolvimento do tema que fora proposto lançou-se mão da pesquisa exploratória e bibiográfica-documental, com método indutivo e qualitativo, utilizando-se, substancialmente, a jurisprudência e doutrina especializada.

Buscou-se, inicialmente, demonstrar o tratamento constitucional e infraconstitucional conferido à proteção ambiental, bem como a identificação do meio ambiente hígido como direito fundamental da pessoa humana e os mecanismos de efetivação deste direito posto pelo constituinte, notadamente a criação de espaços ambientais territoriais a serem especialmente protegidos.

Em seguida, busca-se investigar o direito a propriedade privada como direito fundamental, enfocando a sua função social e os reflexos da diferenciação entre propriedade rural e urbana. Aborda-se, de igual modo, algumas questões referentes ao parcelamento do solo urbano regulado pela Lei $n^{\circ} 6.766 / 1979$.

$\mathrm{Na}$ etapa seguinte, passa-se à análise dos contornos jurídicos que cercam o instituto da área de Reserva Florestal Legal, abordando elementos como a sua finalidade, previsão normativa, conceito e demais aspectos necessários para consubstanciar a análise da sua constituição em áreas urbanas ou de expansão urbana.

Por fim, após este aporte teórico, pretende-se demonstrar que, após a edição no novel Código Florestal não mais persistem obscuridades acerca da possibilidade do Poder Público exigir a manutenção da Reserva Florestal Legal em imóveis situados em áreas urbanas ou de expansão urbana definidas em lei, se estes mantiverem a finalidade rural, isto é, desenvolvendo atividade agrícola, pecuária, extrativista florestal ou agroindustrial. 


\title{
1. O direito ao meio ambiente ecologicamente equilibrado
}

Diante da adoção do modelo de produção capitalista (e de todas as suas consequências no decorrer da história) duas grandes tendências gradativamente foram ganhando espaço nos últimos tempos: a proteção do meio ambiente e a busca da sadia qualidade de vida.

O sistema normativo de proteção ambiental, refletindo esta realidade, vem construindo um importante arcabouço legal de proteção ao meio ambiente, tendo como base central o artigo 225 da Constituição da República, o qual estabelece o direito/dever de todos, incluindo o Poder Público, de preservar o meio ambiente equilibrado para as presentes e futuras gerações.

Silva (2004, p. 52), com propriedade ímpar, afirma que o referido dispositivo compreende três conjuntos de norma:

\begin{abstract}
O primeiro aparece no caput, onde se inscreve a norma matriz, reveladora do direito a todos ao meio ambiente ecologicamente equilibrado; o segundo encontra-se no $\S$ $1^{\circ}$, com seus incisos, que versa sobre os instrumentos de garantia e efetividade do direito enunciado no caput do artigo; o terceiro compreende um conjunto de determinações particulares, em relação a objetos e setores, referidos nos $\S \S 2^{\circ}$ a $6^{\circ}$ que, por tratarem de áreas e situações de elevado conteúdo ecológico, mereceram desde logo proteção constitucional.
\end{abstract}

Ao conceder ao meio ambiente a qualidade de bem de uso comum do povo o legislador reconheceu sua natureza de direito público subjetivo, pois quem usufrui de um bem de uso comum do povo não pode ser determinado, o bem é usufruído por toda a coletividade indistintamente, ou seja, ninguém tem o direito de uso exclusivo ou de privilégios na utilização do bem. Portanto, o direito a um meio ambiente equilibrado, ao ser reconhecido como direito público subjetivo, torna-se um direito exigível a qualquer momento frente ao poder público.

Este direito/dever de preservação ambiental está intimamente ligado ao direito à vida e à dignidade da pessoa humana, já que somente usufruindo de um meio ambiente minimamente hígido é que se alcançará uma vida digna, razão pela qual o direito ao meio ambiente ecologicamente equilibrado elevou-se ao status de direito fundamental.

Referindo-se à simetria entre o direito ao meio ambiente e o direito à vida da pessoa humana, Silva (2004, p. 70) assevera que:

O que é importante é que se tenha a consciência de que o direito à vida, como matriz de todos os demais direitos fundamentais do Homem, é que há de orientar todas as formas de atuação no campo da tutela do meio ambiente. Cumpre compreender que é um fator preponderante, que há de estar acima de quaisquer outras considerações como as de desenvolvimento, como as de respeito ao direito de propriedade, como 
as da iniciativa privada. Também estes são garantidos no texto constitucional, mas, a toda evidência, não podem primar sobre o direito fundamental à vida, que está em jogo quando se discute a tutela da qualidade do meio ambiente. É que a tutela da qualidade do meio ambiente é instrumental no sentido de que, através dela, o que se protege é um valor maior: a qualidade da vida.

Ainda interessante apontar a ponderação de Sampaio, Wold e Nardy (2003, p. 98) no seguinte sentido:

\begin{abstract}
Não bastasse a existência das condições formais de um direito fundamental, o direito ao meio ambiente ecologicamente equilibrado ainda goza de relevo especial na missão de tutelar e de desenvolver o principio da dignidade da pessoa humana ou como desdobramento imediato da corres ponsabilidade Intergeracional.
\end{abstract}

$\mathrm{O}$ direito a um meio ambiente equilibrado, como todo direito fundamental, é um direito indisponível, que não está na disponibilidade de ninguém, nem de pessoa física nem de pessoa pública, pelo fato de que a preservação do meio ambiente deve ser feita no interesse não só das presentes como das gerações futuras.

O conceito legal de meio ambiente é previsto na Lei n. ${ }^{\circ}$ 6.938/1981 (Política Nacional do Meio Ambiente), em seu art. $3^{\circ}$, inciso I, como "o conjunto de condições, leis, influências e interações de ordem física, química e biológica, que permite, abriga e rege a vida em todas as suas formas". No entender de Paulo Affonso Leme Machado (2008, p. 968) a referida lei definiu o meio ambiente da forma mais ampla possível, fazendo com que este se estendesse à natureza como um todo de um modo interativo e integrativo.

De acordo com Fiorillo (2004, p. 20), o conceito legal de meio ambiente se trata de:

...uma definição jurídica indeterminada, assim colocada de forma proposital pelo
legislador com vistas a criar um espaço positivo de incidência da norma', ou seja,
se houvesse uma definição exata de meio ambiente, várias situações poderiam deixar
de serem abarcadas, pela eventual criação de um espaço negativo próprio de
qualquer definição.

Como dito, a Constituição impõe ao cidadão e ao Poder Público a proteção do meio ambiente, isto é, não se trata mais de ato discricionário e sim de determinação legal. Ao inserir a proteção ao meio ambiente como direito fundamental, cuidou o ordenamento de prever garantias e meios de proteção desse bem.

Nery Júnior e Nery (2009, p. 688) afirmam que a Constituição Federal de 1988, em seu art. 225, "considera o direito ao meio ambiente sadio como direito fundamental do cidadão e, ao mesmo tempo, a preservação do meio ambiente como tarefa do Estado". 
Nesse sentido, verifica-se que o constituinte impôs, dentre as incumbências do Poder Público em face da preservação do ambiente, a criação de "espaços territoriais e seus componentes a serem especialmente protegidos", conforme disciplina o artigo 225 , §1, III, in verbis:

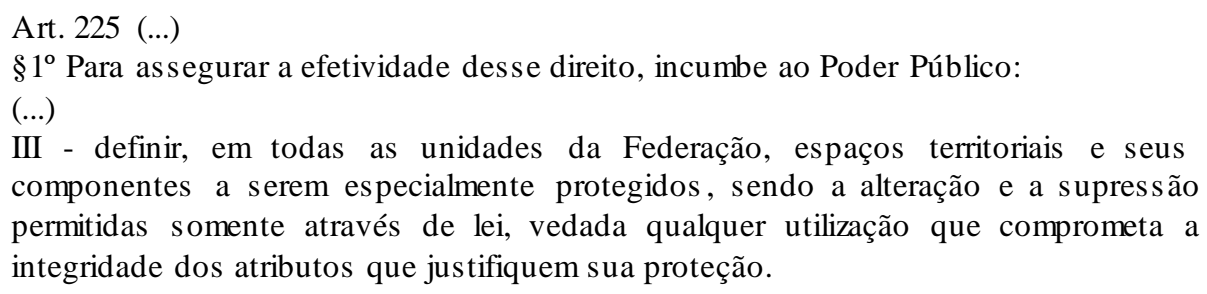

Dentre estes espaços especialmente protegidos, nos interessa destacar a Reserva Florestal Legal, que vem se mostrando um importante instrumento para o alcance da chamada função socioambiental da propriedade.

\section{2. $\mathrm{O}$ direito à propriedade e sua função socioambiental}

Ao lado do direito ao meio ambiente ecologicamente equilibrado, a Constituição Federal também consagra o princípio da propriedade privada. Neste momento, passa-se à análise dos contornos jurídico-históricos deste instituto, enfatizando a função socioambiental da propriedade, assim como a possibilidade de relativização deste direito face à tutela do meio ambiente sadio.

Inicialmente, faz-se necessário apontar que propriedade não se confunde com o direito à propriedade. Em verdade, a primeira é objeto deste último, conforme esclarece Mello (1987, p. 39):

\footnotetext{
Direito de propriedade é a expressão juridicamente reconhecida à propriedade. É o perfil jurídico da propriedade. É a propriedade, tal como configurada em dada ordenação normativa. É, em suma, a dimensão ou o âmbito de expressão legítima da propriedade: aquilo que o direito considera como tal. Donde, as limitações ou s ujeições de poderes do proprietário impostas por um sistema normativo não se constituem em limitações de direitos, pois não comprimem nem deprimem o direito de propriedade, mas, pelo contrário, consistem na própria definição deste direito, compõem seu delineamento e, deste modo, lhe desenham contornos. Na Constituição - e nas leis que lhe estejam conformadas - reside o traçado da compostura daquilo que chamamos direitos de propriedade em tal ou qual país, na época tal ou qual.
}

Importante destacar que o conceito de propriedade refere-se não somente a bens imóveis, mais também a objetos móveis e, inclusive, bens imateriais. 
Esclarecido este ponto, mister apresentar as contornos referentes à propriedade para, em seguida, passar-se ao exame do direito à propriedade na legis lação pátria.

Quanto à origem da propriedade destacam-se as teorias da natureza humana e a teoria da lei. Grosso modo, a primeira dispõe que a propriedade é um direito natural, inerente ao homem, isto é, existindo o homem, existe a propriedade. Ao passo que a teoria da lei, sustentada pelos positivistas, defende que a propriedade é instituto criado e garantido por lei, portanto, depende da prévia existência do Estado, não sendo natural ao homem.

Neste passo, Fonseca (2011, p. 17) alerta que:

\begin{abstract}
...independentemente do entendimento adotado é inegável que a evolução do instituto da propriedade ao longo da história ganha maior relevância a partir do surgimento do Estado, principalmente quanto à individualização da propriedade, a qual está diretamente relacionada à conquista de liberdade pelo homem.
\end{abstract}

Frisa-se que, diante da eclosão de manifestações sociais, em especial após a Revolução Francesa e Industrial na Inglaterra no século XVIII, a ideia de propriedade absoluta, exclusiva e perpétua foi enfraquecendo, uma vez que, com a expansão dos meios de produção e massificação dos trabalhadores, apenas pequena parcela da população (burgueses) usufruía desse direito.

A propriedade individual e absoluta passou a se tornar um obstáculo para viabilização da atuação ativa do Estado como promovedor das garantias sociais, surgindo assim, a necessidade de uma relativização desse conceito liberal de propriedade. Desponta, a partir daí, fruto de um processo lento e marcado por lutas sociais, uma nova percepção de propriedade, com ênfase na sua função social.

Conforme leciona Monteiro (1994, p. 84), o conceito romano de propriedade retratava que o proprietário detinha a faculdade de: i) usar a coisa, retirando dela todos os benefícios que ela o possibilite, sem que isso altere sua substância; ii) gozar, aproveitar de todos os frutos que a coisa gerar; iii) dispor a coisa, permitindo ao proprietário deteriorar, consumir, emprestá-la, aliená-la, inclusive destruí-la se assim o pretender.

$\mathrm{Na}$ legislação pátria, os atributos da propriedade sofreram adaptações no decorrer da história sem, contudo, deixar de constar nos enunciados dos direitos fundamentais de todas as Constituições Brasileiras. Na Constituição de 1988, o direito de propriedade está garantido no artigo $5^{\circ}$, inciso XXII.

Ademais, o constituinte de 1988 afirmou a propriedade privada e sua função social como princípios da Ordem econômica e financeira (artigo 170, incisos II e III), tornando-as 
instrumentos necessários para a consecução da justiça social e, consequentemente, da vida digna.

O Código Civil Brasileiro de 2002 dispõe acerca dos poderes inerentes à propriedade, ao mesmo tempo em que evidencia as limitações que este direito pode sofrer:

\begin{abstract}
Art. 1.228. O proprietário tem a faculdade de usar, gozar e dispor da coisa, e o direito de reavê-la do poder de quem quer que injustamente a possua ou detenha. $\S 1^{\circ} \mathrm{O}$ direito de propriedade deve ser exercido em consonância com as suas finalidades econômicas e sociais e de modo que sejam preservados, de conformidade com o estabelecido em lei especial, a flora, a fauna, as belezas naturais, o equilíbrio ecológico e o patrimônio histórico e artístico, bem como evitada a poluição do ar e das águas. (grifado)
\end{abstract}

Da análise do regramento acima, depreende-se que o legislador não pretendeu estabelecer um conceito legal de propriedade, a qual deve ser ponderada considerando o contexto social, histórico e geográfico em que está inserido. Infere-se, ainda, que a faculdade de o proprietário usar, gozar, dispor e reaver a coisa somente poderá ser exercida em consonância com os fins sociais e econômicos, além do atendimento as normas ambientais, sob pena de the ser retirada a proteção constitucional conferida à propriedade.

A Constituição Federal também menciona expressamente limitações ao direito de propriedade ao afirmar que: "a propriedade urbana atenderá a sua função social" (artigo $5^{\circ}$, inciso XXIII); "a propriedade urbana cumpre sua função social quando atende às exigências fundamentais de ordenação da cidade expressas no plano diretor" (artigo 182, § $2^{\circ}$ ); "a função social é cumprida quando a propriedade rural atende, simultaneamente, segundo critérios e graus de exigência estabelecidos em lei, aos seguintes requisitos: I - aproveitamento racional e adequado; II - utilização adequada dos recursos naturais disponíveis e preservação do meio ambiente; III - observância das disposições que regulam as relações de trabalho; IV exploração que favoreça o bem-estar dos proprietários e dos trabalhadores" (artigo 186).

Como se observa, a função social da propriedade possui respaldo em dois grandes instrumentos jurídicos - a Constituição Federal e Código Civil - para a relativização dos atributos absoluto, exclusivo e perpétuo que recaiam sobre o tradicional direito de propriedade.

Nota-se que, na medida em que trata dos seus elementos, como a proteção à flora, à fauna, à preservação das belezas naturais, à manutenção do equilibrio ecológico e a preservação patrimônio histórico e artístico, assim como o uso da propriedade em consonância com as normas ambientais, a legislação pátria confere também uma função 
ambiental à propriedade, onde o particular e o Poder Público passam a ter um poder/dever em favor da sociedade, titular do direito ao meio ambiente equilibrado.

Borges (1999, p.116) define a função ambiental da propriedade como "o conjunto de deveres imputados ao proprietário em face da necessidade de manutenção do equilíbrio ecológico e como elemento da função social da propriedade" conteúdo determinado pelo texto constitucional.

Nessa esteira, para garantir a efetividade da proteção ao meio ambiente e, de forma reflexa, à própria perpetuidade da vida, é inevitável a adoção de medidas interventivas pelo Estado frente aos direitos individuais, incluindo o direito à propriedade.

Pois, como mencionado, a propriedade não é um direito absoluto. Sua função social se consubstancia em um complexo de determinações que visam à compatibilidade da propriedade com os interesses sociais, os quais, por óbvio, o meio ambiente integra.

\section{Propriedade rural $x$ propriedade urbana}

No tocante à definição de propriedade urbana ou rural destacam-se dois critérios para se aferir a natureza urbana ou rural da propriedade: critério da destinação/finalidade e critério geográfico/territorial.

Conforme o critério da destinação ou finalidade, ainda que o imóvel se localize em área urbana, se neste for desenvolvida atividade agrícola, pecuária, extrativista florestal ou agroindustrial, será considerado rural.

Por outro lado, pelo critério da localização o imóvel inserido em área urbana definida por lei será urbano e, consequentemente, os que tiverem fora da área urbana serão considerados rurais, independentemente da sua destinação.

O primeiro dispositivo legal a tratar especificamente do assunto foi a Lei n. $^{\circ}$ 4.504/1964, o "Estatuto da Terra", que definiu o imóvel rural no seu Art. 4, I:

I - 'Imóvel Rural, o prédio rústico, de área contínua qualquer que seja a sua localização que se destina à exploração extrativa agrícola, pecuária ou agro industrial, quer através de planos públicos de valorização, quer at ravés de iniciativa privada;

Como se nota, o artigo mencionado adotou como critério identificador do imóvel rural a sua destinação à exploração de atividade agrícola, pecuária ou agroindustrial, pouco importando a sua localização, seja na área urbana ou rural do Município. 
Entretanto, com a elaboração do Código Tributário Nacional (Lei nº 5.172/66) emerge uma nova polêmica quanto à caracterização de imóveis rurais e urbanos, já que o referido dispositivo legal adota o critério da localização, conforme se extrai dos artigos 29 e 32, in verbis:

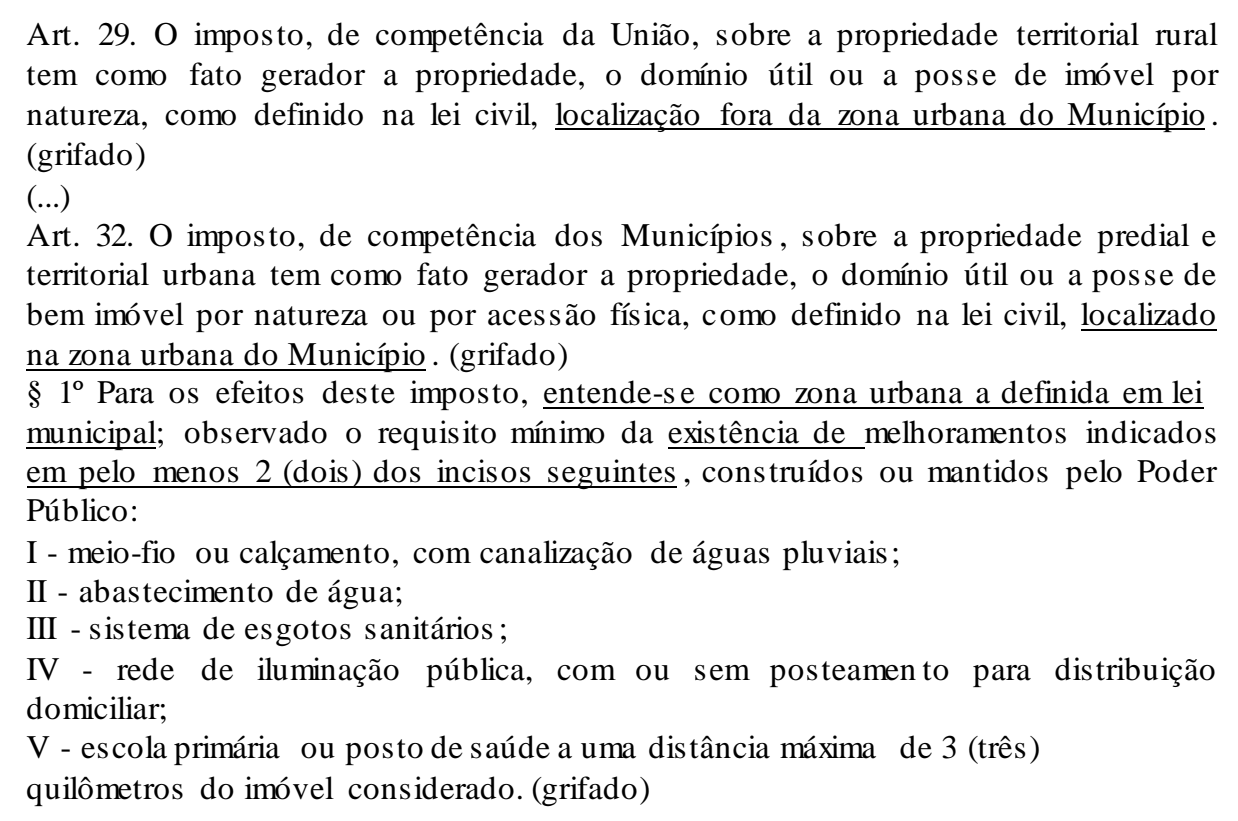

Sem dúvidas, a adoção do critério da localização para definição do imóvel como rural ou urbano se mostra mais vantajosa aos entes municipais, vez que estes estão sempre à busca de novas receitas através da publicação de leis locais estendendo as áreas urbanas.

Importante ressaltar que após o Código Tributário, foram editados o Decreto $\mathrm{n}^{\circ}$. 59.428/66, regulamentando o "Estatuto da Terra", e o Decreto-lei no 57/66, ambos reforçando a adoção do critério da destinação para definição de propriedade rural ou urbana.

Destaca-se, aqui, o artigo 15 do Decreto-lei $n^{\circ}$ 57/66, o qual dispôs expressamente que os imóveis destinados a explorações extrativa, agrícola, pecuária ou agroindustrial estariam sujeitos ao Imposto Territorial Rural independente da sua localização:

Art. 15. O disposto no art. 32 da Lei $n^{\circ} 5.172$, de 25 de outubro de 1966, não abrange o imóvel de que, comprovadamente, seja utilizado em exploração extrativa vegetal, agrícola, pecuária ou agro-industrial, incidindo assim, sobre o mesmo, o ITR e demais tributos com o mes mo cobrado.

A propriedade urbana e a rural foram disciplinadas no Texto Constitucional no título referente à "Ordem Econômica e Financeira", onde a primeira integra o capítulo da "Política Urbana" e a segunda, o capítulo da "Política Agrícola e Fundiária e da Reforma Agrária". 
A "Política Urbana" foi regulamentada pelo Estatuto da Cidade (Lei no 10.257/2001) que, apesar de não trazer em seu bojo a definição de propriedade urbana, determinou a obrigatoriedade da elaboração e a aprovação de Plano Diretor para os Municípios com mais de 20 mil habitantes, e que o referido plano devesse conter, no mínimo, as delimitações das áreas urbanas onde pode ser aplicado o parcelamento, a edificação ou a utilização compulsória dessas áreas, bem como as áreas que poderão ter o uso do solo alterado, desde que realizada uma contrapartida pelo beneficiário (artigo 41 e 42).

Outrossim, cumpre ainda aduzir que, para a definição da zona urbana pelo Município, é indispensável a observância do $\S 1^{\circ}$ do artigo 32 do Código Tributário Nacional, o qual exige a disponibilização, pelo ente federativo municipal, de pelo menos dois dos seguintes melhoramentos: i) meio-fio ou calçamento; ii) abastecimento de água; iii) sistema de esgoto; iv) iluminação pública; v) escola primária ou posto de saúde localizados a pelo menos três quilômetros do imóvel, com exceção daquelas propriedades que estiverem localizadas no perímetro urbano, mas que estejam destinadas à exploração rural.

Por outro lado, a "Política Agrária" fora regulamentada por meio da Lei n. $8.629 / 93$, que trouxe em seu artigo $4^{\circ}$ a definição de imóvel rural, cujo entendimento veio ao encontro do disposto no artigo 15 do Decreto-lei n. ${ }^{\circ}$ 57/66, adotando o critério da destinação:

Art. $4^{\circ}$ Para os efeitos desta lei, conceituam-s e:

I - Imóvel Rural - o prédio rústico de área contínua, qualquer que seja a sua localização, que se destine ou possa se destinar à exploração agrícola, pecuária, extrativa vegetal, florestal ou agro-industrial;

Como já mencionado alhures, conforme o critério da finalidade ou destinação o imóvel é interpretado como urbano se, concomitantemente, estiver localizado no perímetro urbano do Município, a ser definido pelo Plano Diretor, e cuja atividade não seja a exploração agrícola, pecuária, extrativa-vegetal, florestal ou agroindustrial, pois a propriedade rural é aquela destinada a fins rurais, independentemente de sua localização.

Importante pontuar que o Superior Tribunal de Justiça, em matéria tributária, já se posicionava a favor da aplicação deste critério para definição de propriedade rural ou urbana:

TRIBUTÁRIO. IPTU OU ITR. IMÓVEL LOCALIZADO EM ÁREA URBANA. NATUREZA DO IMÓVEL. REVISÃO DAS CONCLUSÕES DO TRIBUNAL DE ORIGEM. IMPOSSIBILIDADE. SÚMULA 7/STJ. 1. A jurisprudência desta Corte Superior é no sentido de que incide o ITR e, não, o IPTU sobre imóve is nos quais s ão comprovadamente utilizados em exploração extrativa, vegetal, agrícola, pecuária ou agroindustrial, ainda que localizados em áreas consideradas urbanas por legis lação municipal. 2. Hipótese em que o acórdão recorrido é claro em afirmar que 
o imóvel possui como atividade preponderante o beneficiamento e a comercialização de arroz, e que não se trata de atividade agropecuária ou agroindus trial. Assim, para mudar tal entendimento, seria imprescindível adentrar a seara dos fatos para apurar, conforme alega o recorrente, que o imóvel em questão possui natureza industrial, o que esbarra na Súmula 7/STJ: "A pretensão de simples reexame de prova não ens eja recurso especial". 3. Agravo regimental não provido. (STJ - AgRg no AREsp: 323705 RS 2013/0096886-0, Relator: Ministro HERMAN BENJAMIN, Data de Julgamento: 15/08/2013, T2 - SEGUNDA TURMA, Data de Publicação: DJe 16/09/2013)

TRIBUTÁRIO. IPTU. IMÓVEL LOCALIZADO EM ÁREA URBANA. EXPLORAÇÃO DE ATIVIDADES ESSENCIALMENTE RURAIS. IPTU. NÃOINCIDÊNCIA. PRECEDENTE. 1. Não incide IPTU, mas ITR, sobre imóveis nos quais são exploradas atividades essencialmente rurais, ainda que localizados em áreas consideradas urbanas por legislação municipal. Precedente: REsp 1.112.646/SP, Rel. Min. Herman Benjamin, Primeira Seção, DJe 28/08/2009, submetido ao art. 543-C do CPC e da Resolução 8/2008 do STJ. 2. Todavia, no caso dos autos, o Tribunal de origem não se manifestou de forma específica sobre as atividades desenvolvidas no imóvel dos recorrentes, o que impossibilita o conhecimento do recurso por incidência da Súmula 7/STJ. 3. Ainda que assim não fosse, extrai-se da sentença, que o imóvel seria objeto de parcelamento para fins urbanos (implantação de loteamento residencial), já aprovado pelas autoridades competentes e em fase de implantação, o que afastaria a incidência do ITR. 4. Recurso especial não conhecido. (STJ - REsp: 1150408 SP 2009/0074333-1, Relator: Ministro CASTRO MEIRA, Data de Julgamento: 28/09/2010, T2 SEGUNDA TURMA, Data de Publicação: DJe 19/10/2010)

\section{Parcelamento do solo urbano}

A regulação do parcelamento do solo urbano se dá, basicamente, pela Lei $\mathrm{n}^{\circ}$ 6.766/1979 (recepcionada pela Carta Magna), que compreende normas urbanísticas, sanitárias, civis e penais visando a disciplinar a ocupação do solo e o desenvolvimento urbano, assim como a tutela do interesse público coletivo envolvido.

Sobre o tema, Silva (1981, p. 373) observa que o parcelamento do solo visa a urbanificação de uma gleba, mediante sua divisão ou redivisão em parcelas destinadas ao exercício das funções elementares urbanísticas.

Já Couto (1981, p. 8) entende que o parcelamento do solo com fins urbanos refere-se ao fracionamento do espaço territorial especificamente destinado a abrigar contingentes humanos para formação, expansão ou conservação das cidades.

Das lições apontadas acima, podemos concluir que o parcelamento do solo para fins urbanos tem como finalidade precípua ordenar o espaço urbano destinado a habitação.

A Lei $n^{\circ} 6.766 / 1979$ dispõe que o parcelamento do solo poderá ocorrer por via do loteamento ou por via do desmembramento, conforme o artigo $2^{\circ}, \S 1^{\circ}$ e $\S 2^{\circ}$.

Art. $2^{\circ}$ - O parcelamento do solo urbano poderá ser feito mediante loteamento ou desmembramento, observadas as disposições desta Lei e as das legislações estaduais e municipais pertinentes. 
$\S 1^{\circ}$ - Considera-se loteamento a subdivisão de gleba em lotes destinados a edificação, com abertura de novas vias de circulação, de logradouros públicos ou prolongamento, modificação ou ampliação das vias existentes.

$\S 2^{\circ}$ - considera-se desmembramento a subdivisão de gleba em lotes destinados a edificação, com aproveitamento do sistema viário existente, desde que não implique na abertura de novas vias e logradouros públicos, nem no prolongamento, modificação ou ampliação dos já existentes.

Como se observa do regramento acima, o loteamento e o desmembramento constituem modalidades do parcelamento do solo. Contudo, apresentam características diversas, conforme esclarece Meirelles (2000, p. 465):

\footnotetext{
"o loteamento é meio de urbanização e só se efetiva por procedimento voluntário e formal do proprietário da gleba, que planeja a sua divisão e a submete à aprovação da Prefeitura, para subsequente inscrição no Registro Imobiliário, transferência gratuita das áreas das vias públicas e espaços livres ao Município e a alienação dos lotes aos interessados; o desmembramento é apenas repartição da gleba, sem atos de urbanização, e tanto pode ocorrer pela vontade do proprietário (venda, doação etc.) como por imposição judicial (arrematação, partilha etc.), em ambos os casos s em qualquer transferência de área ao domínio público”. (grifado)
}

A referida Lei ainda estabelece as regras para registro imobiliário do loteamento ou desmembramento do imóvel para fins urbanos, dispondo que, após a aprovação do projeto de loteamento, o loteador deverá submetê-lo ao registro imobiliário dentro de 180 (cento e oitenta) dias, sob pena de caducidade da aprovação (artigo18).

\section{Aspectos relevantes da Reserva Florestal Legal}

Como informado anteriormente, cabe ao Estado criar espaços territoriais e seus componentes a serem especialmente protegidos (artigo 225, $\S 1^{\circ}$, inciso III) com o intuito de assegurar o direito ao meio ambiente hígido.

Dentre estes espaços, destaca-se a área de Reserva Florestal Legal a qual passamos a breve exame, esclarecendo, desde já, que não se objetiva esgotar a análise deste instituto, mas, tão somente, construir o aporte teórico necessário para a discussão sobre o objeto deste trabalho, qual seja, a constituição da Reserva Florestal Legal em áreas urbanas e de expansão urbana.

Instituto previsto no Código Florestal (Lei 12.651/12), a Reserva Florestal Legal se refere à área localizada no interior de uma propriedade ou posse rural com a função de assegurar o uso econômico de modo sustentável dos recursos naturais do imóvel rural, auxiliar a conservação e a reabilitação dos processos ecológicos e promover a conservação da 
biodiversidade, bem como o abrigo e a proteção de fauna silvestre e da flora nativa (art. $3^{\circ}$, III).

Extrai-se do regramento acima que a área de Reserva Florestal Legal constitui limitação administrativa ao uso da propriedade privada visando tutelar o meio ambiente. Trata-se de obrigação propter rem, ou seja, é uma obrigação ambulatória, em razão da coisa, que adere ao Título de propriedade ou de posse.

Tal instituto tem o escopo de adequar a tríplice função da propriedade: econômica, social e ambiental. Nas palavras de Machado (2008, p. 757) "usa-se menos a propriedade, para usar-se sempre".

Em termos gerais, a Reserva Florestal Legal representa uma parcela da posse ou propriedade rural que deve ser mantida com vegetação nativa e uso restrito. Sua extensão, delimitada pelo artigo 12 do Código Florestal, varia de acordo com a localização geográfica e o bioma no qual o imóvel está inserido.

Nesse aspecto, cumpre destacar o objetivo da inserção do instituto da Reserva Florestal Legal, de acordo com Antunes (2001, p. 117):

\begin{abstract}
As áreas de reserva legal foram instituídas pelo Código Florestal com uma função específica de manter um equilíbrio ecológico, mantendo regulado os regimes de chuvas, do clima, da absorção de gases, de partículas poluentes e, sobretudo, garantir as demandas das gerações futuras, especialmente no que se refere a princípios ativos de plantas medicinais que poderão representar a cura de doenças que nem existem atualmente. O legislador também buscou garantir a preservação das espécies, posto que as reservas se transformariam em verdadeiros bancos genéticos. Teriam ainda a função de suprir demanda de árvores para o fornecimento de madeira e demais necessidades.
\end{abstract}

Frise-se que, em regra geral, a manutenção da área de Reserva Florestal Legal somente é exigível em imóveis rurais, conforme estipula o artigo 12 do Código Florestal:

\footnotetext{
Art. 12 - Todo imóvel rural deve manter área com cobertura de vegetação nativa, a título de Reserva Legal, sem prejuízo da aplicação das normas sobre as Áreas de Preservação Permanente, observados os seguintes percentuais mínimos em relação à área do imóvel, excetuados os casos previstos no art. 68 des ta Lei: I - localizado na Amazônia Legal:

a) $80 \%$ (oitenta por cento), no imóvel situado em área de florestas;

b) $35 \%$ (trinta e cinco por cento), no imóvel situado em área de cerrado;

c) $20 \%$ (vinte por cento), no imóvel situado em área de campos gerais;

II - localizado nas demais regiões do País: $20 \%$ (vinte por cento).
}

A referida Lei impõe, no caput do artigo 17, ao proprietário do imóvel rural, possuidor ou ocupante a qualquer título, pessoa física ou jurídica, de direito público ou 
privado, a conservação da cobertura de vegetação nativa da Reserva Florestal Legal. Andou bem o legislador ao utilizar a expressão conservar, pois o novel Código Florestal autoriza a exploração econômica sustentável da Reserva Florestal Legal, mediante manejo florestal sustentável previamente aprovado pelo órgão ambiental competente.

Importante apontar que a área de Reserva Florestal Legal deve ser registrada no órgão ambiental competente por meio da inscrição no CAR (artigo 18), não sendo mais obrigatória a sua averbação à margem da matrícula do imóvel.

\section{Manutenção da área de Reserva Florestal Legal em área urbana ou de expansão urbana}

O novel Código Florestal estabelece a obrigatoriedade de manutenção da área de Reserva Legal em todos os imóveis rurais. Sobre esta questão, necessário apontar um ponto de certo modo controvertido na doutrina e jurisprudência quando do antigo Código Florestal (Lei 4.771/65): a manutenção da Reserva Florestal Legal em área urbana ou de expansão urbana.

Como visto, havia uma grande celeuma sobre a distinção entre propriedade rural e propriedade urbana. Por muito tempo se discutiu sobre a necessidade ou não de manutenção da Reserva Florestal Legal no imóvel quando Lei Municipal o inseria em área urbana.

Após o retrospecto das normas pertinentes a matéria, percebe-se que o cenário normativo da época ensejava uma enorme insegurança jurídica, abrindo espaço para grandes embates sobre a necessidade de manutenção da Reserva Florestal Legal em áreas urbanas.

Fonseca (2011, p. 137), se referindo à questão em 2011, faz uma leitura muito coerente sobre a realidade à época, mas que se aplica facilmente aos dias de hoje:

\footnotetext{
Não suficiente a complacência do Estado e o desrespeito dos proprietários rurais à norma posta, observa-se que as áreas de "reserva legal" têm seu conteúdo e efetividade diminuídos em face do êxodo rural, acontecimento inevitável que vêm ocorrendo no Brasil, principalment e a partir dos anos 1980. Fenômeno que contribui intensamente para o crescimento das cidades, as quais passam a ocupar áreas que anteriormente eram destinadas a fins rurais, resultando no desaparecimento das áreas de "reserva legal".
}

Todavia, após a edição da Lei 12.651/12 (novo Código Florestal) não persistem motivos para tais controvérsias. Isso porque o artigo 19 do referido diploma legal não deixa margem a qualquer dúvida quanto à temática, conforme se observa: 
Art. 19. A inserção do imóvel rural em perímetro urbano definido mediante lei municipal não desobriga o proprietário ou posseiro da manutenção da área de Reserva Legal, que só será extinta concomitantemente ao registro do parcelamento do solo para fins urbanos aprovado segundo a legislação específica e consoante as diretrizes do plano diretor de que trata o $\S 1^{\circ}$ do art. 182 da Cons tituição Federal. (grifado)

Pois bem, o sobredito artigo 19 do Código Florestal é cristalino ao dispor que a inserção do imóvel rural em perímetro urbano definido mediante lei municipal, por si só, não desobriga o proprietário ou posseiro da manutenção da área de Reserva Florestal Legal. Somente o registro do parcelamento do solo para fins urbanos extingue o referido instituto.

Com a exigência do parcelamento do solo para fins urbanos, nota-se, portanto, que o novo Código Florestal adotou o critério da destinação econômica do imóvel para reconhecê-lo como rural ou urbano, sendo necessário analisar a atividade desenvolvida no imóvel, ainda que localizado em área urbana, assim definida por lei municipal.

Aliás, necessário reafirmar o interesse dos Municípios em instituírem áreas urbanas no afã de arrecadar receitas através da cobrança do IPTU. Nesse aspecto Milaré e Machado afirmam (2012, p. 258):

...é cediço que muitos municípios instituem áreas (ou zonas) urbanas com o intuito
primordial de cobrar IPTU - Imposto sobre a propriedade predial e territorial urbana
- e aumentar a arrecadação, dentre outros interesses não tão legítimos, sem a
observância, pois, tanto do disposto no art. $32, \S 1^{\circ}$, do CTN quanto do art. 47 , II da
Lei $11.977 / 2009$. Por exemplo, há áreas consideradas urbanas por leis municipais,
mas que não têm o mínimo de infraestrutura, como energia elétrica e água,
enquanto, em outros casos, existem leis locais que consideram todo o território como
zona urbana, o que pode caracterizar desvio de finalidade da lei.

Neste prisma, o legislador optou por desobrigar à manutenção da Reserva Florestal Legal apenas àquele que pretende utilizar o solo para fins urbanos, através do parcelamento do solo para este fim e não somente pela existência de lei Municipal inserindo-o em perímetro urbano. Isto é, o que caracterizará o imóvel como urbano, para fins de extinção da Reserva Florestal Legal, será o registro do seu parcelamento com a finalidade urbana.

Consequentemente, se inexistente o registro no Cartório Imobiliário do parcelamento do solo para fins urbanos, a propriedade ainda será considerada rural e estará sujeita à aplicação do Código Florestal, obrigando-se, assim, à manutenção da área de Reserva Florestal Legal nos limites previstos em lei.

Nesse mesmo norte, impende destacar que as áreas de expansão urbana - aquelas destinadas ao crescimento das cidades, determinadas pelos Planos Diretores - visam apenas 
possibilitar o planejamento das cidades, não possuindo o condão de alterar a destinação de qualquer propriedade.

Cumpre demonstrar a posição da jurisprudência no sentido da exigência de comprovação do registro de parcelamento do solo para fins urbanos para desobrigação da Reserva Florestal Legal:

AGRAVO DE INSTRUMENTO. Ação civil pública. Tutela antecipada deferida para apresentação de projeto, cronograma de recomposição de vegetação e demarcação da área de reserva legal, além do dever de abstenção de explorar o local. Imóvel de inequívoca natureza rural, arrendado para o plantio de cana-deaçúcar. Irrelevância da discussão a respeito de a área ter sido ou não inserida no perímetro urbano. Inteligência do art. 19 da Lei n. 12.651/2012. Registro do parcelamento do solo não comprovado. Presença dos pressupostos legais à tutela antecipada. Decisão mantida. RECURSO DESPROVIDO. (TJ-SP, Relator: Paulo Alcides, Data de Julgamento: 21/03/2013, $1^{\text {a }}$ Câmara Reservada ao Meio Ambiente) (grifado)

AÇÃO CIVIL PÚBLICA. Intervenção irregular em área de preservação permanente, nas margens da represa da Usina Hidrelétrica de Volta Grande. Procedência parcial dos pedidos. Preliminares. Competência da Justiça Estadual para a repressão de dano ambiental estritamente local, ainda que tenha ocorrido em rio qualificado como da União. Nulidade processual não acolhida, em razão da natureza facultativa do inquérito civil. Mérito. Conjunto probatório que evidencia a intervenção irregular em área de preservação permanente e a ausência de instituição da reserva legal. Responsabilidade de natureza objetiva, nos termos do art. 14, $\S 1^{\circ}$, da Lei $n$. 6.938/1981. Ausência de constituição da reserva legal. Obrigatoriedade indiscutível. Aplicação do princípio da função socioambiental da propriedade. Cobrança de IPTU que, por si só, é insuficiente para caracterizar o imóvel como urbano. Sentença mantida. PRELIMINARES REJEITADAS E RECURSO DESPROVIDO. (TJ-SP, Relator: Paulo Alcides, Data de Julgamento: 18/04/2013, $1^{\text {a }}$ Câmara Reservada ao Meio Ambiente) (grifado)

AGRAVO DE INSTRUMENTO. AÇÃO CIVIL PÚBLICA. RESERVA LEGAL. AVERBAÇÃO DA EXISTÊNCIA DA AÇÃO NA MATRÍCULA DO IMÓVEL. POSSIBILIDADE. RECURSO A QUE SE NEGA PROVIMENTO. I - 0 proprietário do imóvel situado no perímetro urbano não está dispensado da instituição da reserva legal se inexistente registro do parcelamento do solo para fins urbanos. II - A averbação no registro do imóvel da existência de ação civil pública destinada à instituição da reserva legal é salutar medida acautelatória, posto preservar eventuais interesses ou direitos de terceiros. (TJ-MG, Relator: Peixoto Henriques, Data de Julgamento: 22/07/2014, Câmaras Cíveis / $7^{\mathrm{a}}$ CÂMARA CÍVEL) (grifado)

Desta forma, resta clara a irrelevância da discussão acerca da área ter sido ou não inserida no perímetro urbano por Lei Municipal ou, ainda, se há cobrança de IPTU haja vista o teor do art. 19 da Lei n. 12.651/2012 que não dispensa a obrigação da parte constituir a reserva legal em áreas urbanas se não registrado o parcelamento do solo para fins urbanos.

De acordo com o artigo 24, incisos I e VI da Constituição Federal, a competência para legislar sobre direito urbanístico e sobre 'florestas, caça, pesca, fauna, conservação da natureza, defesa do solo e dos recursos naturais, proteção do meio ambiente e controle da poluição", é atribuída à União, aos Estados Federados e ao Distrito Federal, de forma 
concorrente. Isto é, cabe à União editar normas gerais e a estes últimos, tão somente, suplementá- las.

Apenas para contextualização, cabe informar que se conceitua o direito urbanístico como "o ramo do Direito Público destinado ao estudo e formulação dos princípios e normas que devem reger os espaços habitáveis, no seu conjunto cidade-campo" (MEIRELLES, 2000, p. 435-436). Portanto, tal instituto disciplina tanto os espaços urbanos quanto rurais, pois qualquer interferência em um pode acarretar consequências no outro, vez que são espaços indissociáveis.

Entretanto, ressalta-se que a interferência do direito urbanístico nas áreas rurais não ocorre de maneira absoluta. Conforme preceitua Meirelles (2000, p. 436), sua atuação limitase aos núcleos populacionais e à análise das implicações ambientais que possam afetar as condições de vida urbanas; por conseguinte, as áreas destinadas à exploração rural não the interessam.

Desta maneira, uma vez que o Código Florestal dispõe sobre a matéria em debate, exigindo o registro do parcelamento do solo par fins urbanos como requisito da extinção da Reserva Florestal Legal em área urbana, não cabe aos Estados e ao Distrito Federal editarem normas em sentido diverso ou menos restritas.

Convém pontuar, ainda, que o artigo 19 do Código Florestal não afronta a competência dos Municípios de promover o ordenamento territorial estabelecida no artigo 30, inciso VIII, da Constituição Pátria. Ora, não se olvida da atribuição conferida ao Município de promover, no que couber, adequado ordenamento territorial mediante planejamento e controle do uso do parcelamento e da ocupação do solo urbano, figurando o Plano Diretor como importante instrumento efetivador da função social da propriedade urbana. Inclusive, o Código Florestal ressalta que o parcelamento do solo deve ser aprovado segundo a legislação específica e consoante as diretrizes do Plano Diretor.

Todavia, em que pese a Constituição autorizar o Município a legislar sobre assuntos de interesse local, realizar o adequado ordenamento do solo, assim como suplementar a legislação federal e estadual no que couber (artigo 30, incisos I, II e III), isso não significa que esteja autorizado, por meio do Plano Diretor, a permitir que as propriedades rurais sejam transformadas em urbanas sem a necessidade da manutenção de Reserva Florestal Legal.

Isso porque, por força constitucional a atuação do Município se limita ao interesse local. Meirelles (200, p. 104) esclarece que "o que define e caracteriza o 'interesse local', inscrito como dogma constitucional, é a predominância do interesse do Município sobre o do Estado ou da União". 
Dessa forma, a despeito do ordenamento urbano, não resta dúvidas que a competência do Município prepondera sobre a dos Estados, Distrito Federal e da União, cabendo ao Município a edição de normas sobre o zoneamento urbano, parcelamento e o uso do solo, e construções edilícias e paisagísticas. Contudo, no tocante às normas ambientais, nas quais se inserem as normas referentes às áreas de Reserva Florestal Legal, trata-se de difuso, cuja titularidade pertence a todos e, ocorrendo a existência de qualquer dano, certamente afetará um número indeterminado de pessoas, extrapolando os limites do Município.

Nesse sentido, Séguin (2006, p. 105) destaca que, no fiel da balança entre questões urbanas e as ecológicas, estas não podem ser vistas como menos importantes, havendo necessidade de serem compatibilizadas as normas para evitar a superposição de esferas e o conflito de atribuições.

\section{Considerações finais}

O meio ambiente, definido como tudo o que nos cerca, vem ganhando cada vez mais proteção jurídica em virtude das constantes pressões que vem sofrendo, o que afeta toda a coletividade em razão do seu caráter difuso. O artigo 225 da Constituição federal, considerado o centro do sistema normativo de proteção ambiental, impõe à sociedade e ao Poder Público a preservação do meio ambiente, conferindo a este direito status de direito fundamental.

Não se olvida do caráter de fundamentalidade incorporado por este direito, uma vez que está intimamente ligado ao direito à vida digna, que só é possível quando presente um meio ambiente minimamente sadio.

Com o intuito de assegurar a efetividade do direito ao meio ambiente ecologicamente equilibrado, o constituinte incumbiu ao Poder Público a definição de espaços territoriais a serem especialmente protegidos, dentre os quais destacou-se a área de Reserva Florestal Legal, prevista no Código Florestal como sendo uma área localizada no interior de uma propriedade ou posse rural com a função de assegurar o uso econômico de modo sustentável dos recursos naturais do imóvel rural, auxiliar a conservação e a reabilitação dos processos ecológicos e promover a conservação da biodiversidade, bem como o abrigo e a proteção de fauna silvestre e da flora nativa (art. $3^{\circ}$, III).

Em que pese a utilização deste instituto implicar na relativização do direito à propriedade, a função socioambiental desta justifica a intervenção do Estado junto à propriedade privada, sob o respaldo da Constituição Federal e do Código Civil Brasileiro, que determinam a utilização da propriedade em consonância com os fins sociais, econômicos e ambientais, sob pena de ser retirada a proteção constitucional que the é conferida. 
Após as considerações acima, e considerando a utilização do critério da destinação para diferenciação entre propriedade urbana e a rural, bem como alguns aspectos referentes ao parcelamento do solo, foi possível concluir, à luz do artigo 19 do Código Florestal, que a inserção do imóvel rural em perímetro urbano definido mediante lei municipal, por si só, não desobriga o proprietário ou posseiro da manutenção da área de Reserva Florestal Legal, que só deve ser extinta após a descaraterização da propriedade rural, mediante a comprovação do registro do parcelamento do solo para fins urbanos.

Em outras palavras, nas hipóteses de propriedade inserida em área urbana ou de expansão urbana, a Reserva Florestal Legal deve ser exigida quando a atividade ali desenvolvida seja a exploração agrícola, pecuária, florestal ou agroindustrial, ou seja, ainda se configure como propriedade destinada a fins rurais.

\section{Referências bibliográficas}

ANTUNES, Paulo Bessa de. Poder Judiciário e "reserva legal": análise de recentes decisões do Superior Tribunal de Justiça. In: Revista de Direito Ambiental, v. 6, n. 21, p. 103-131, jan./mar. 2001. São Paulo: Revista dos Tribunais, 2001.

ANTUNES, Paulo de Bessa. Direito Ambiental. 11. ed. Rio de Janeiro: Lumen Juris, 2008.

BANDEIRA DE MELLO, Celso. Novos aspectos da função social da propriedade no direito público. Revista de Direito Público, v. 20, n. 84, out/dez. 1987.

BORGES, Roxana Cardoso Brasileiro. Função ambiental da propriedade rural. São Paulo: LTr, 1999.

BRASIL. Lei n. ${ }^{o}$ 10.406, de 10 de janeiro de 2002. "Código Civil”. Disponível em: www.planalto.gov.br, acesso em 01/07/15.

BRASIL. Lei n. ${ }^{o}$ 12.651, de 25 de maio de 2012. "Código Florestal". Disponível em: www.planalto.gov.br, acesso em 01/07/15.

BRASIL. Lei $n^{\circ}$ 6.766, de 19 de dezembro de 1979. Disponível em: www.planalto.gov.br, acesso em 17/07/15.

BRASIL. Constituição da República Federativa do Brasil de 1988. Brasilia, DF: Senado, 1988. Disponível em: www.planalto.gov.br, acesso em 01/07/15.

BRASÍLIA. $2^{\text {a }}$ Turma do Superior Tribunal de Justiça, Recurso Especial, AgRg no AREsp: 323705 RS 2013/0096886-0. Relator Min. Herman Benjamin. 15/08/2013. Disponível em: <http://www.stj.jus.br> Acesso em 25 de julho 2015. 
BRASÍLIA. 2 $2^{\mathrm{a}}$ Turma do Superior Tribunal de Justiça, Recurso Especial, REsp: 1150408 SP 2009/0074333-1. Relator Min. Castro Meira. 28/09/2010. Disponível em: $<$ http://www.stj.jus.br> Acesso em 25 de julho 2015.

COUTO, Sérgio Frazão do. Manual prático do parcelamento do solo urbano. Rio de Janeiro: Forense, 1981.

FIGUEIREDO, Guilherme José Purvin de. A propriedade no direito ambiental. São Paulo: Editora Revista dos Tribunais, 4 ed., 2010.

FIORILlO, Celso Antônio Pacheco. Curso de Direito Ambiental Brasileiro. 9. ed. São Paulo: Saraiva, 2004.

FONSECA, Jaquiel R. Hammes da. A exigência de manutenção da área de reserva legal na transformação da propriedade rural em urbana. Dissertação (Mestrado em Direito) - Curso de Direito da Universidade de Marilia, Marilia, 2011.

MACHADO, Paulo Affonso L. Direito Ambiental Brasileiro. 14 ed. SP: Malheiros, 2008.

MEIRELLES, Helly Lopes. Direito Municipal Brasileiro. 11. ed. São Paulo: Malheiros, 2000. MILARÉ, Edis. Direito do Ambiente. São Paulo: Revista dos Tribunais, 2014.

MILARÉ, Edis; MACHADO, Paulo Affonso Leme - Coord. Novo Código Florestal Comentários à Lei 12.651, de 25 de maio de 2012 e à MedProv 571, de 25 de maio de 2012. 1 ed. São Paulo: Editora Revista dos Tribunais, 2012.

MINAS GERAIS. 7 ${ }^{a}$ Câmara Cível do Tribunal de Justiça do Estado de Minas Gerais. Agravo de Instrumento. 1.0702.12.078440-1/001. Relator: Peixoto Henriques. 22/07/2014. Disponível em: <http://www.tjmg.jus.br> Acesso em 25 de julho 2015.

MONTEIRO, Washington de Barros. Curso de Direito Civil. v. 3. 31. ed. São Paulo: Saraiva, 1994.

NERY JÚNIOR, Nelson; NERY, Rosa Maria de Andrade. Constituição federal comentada e legislação constitucional. 2. ed. São Paulo: Revista dos Tribunais, 2009.

SAMPAIO, José Adércio Leite; WOLD, Cris; NARDY, Afrânio. Princípios de direito ambiental na dimensão internacional e comparada. Belo Horizonte: Del Rey, 2003.

SÃO PAULO. $1^{\text {a }}$ Câmara Reservada ao Meio Ambiente do Tribunal de Justiça do Estado de São Paulo. Agravo de Instrumento. 0267882-15.2011.8.26.0000. Relator: Paulo Alcides. 21/03/2013. Disponível em: <http://www.tjsp.jus.br> Acesso em 25 de julho 2015.

SÃO PAULO. $1^{\text {a }}$ Câmara Reservada ao Meio Ambiente do Tribunal de Justiça do Estado de São Paulo. Ação Civil Pública. 0001699-09.2001.8.26.0352,. Relator: Paulo Alcides. 18/04/2013. Disponível em: <http://www.tjsp.jus.br> Acesso em 25 de julho 2015. 
SARLET, Ingo Wolfgang; FENSTERSEIFER, Tiago. Direito Constitucional ambiental: estudos sobre a constituição, os direitos fundamentais e a proteção do ambiente. SARLET, Ingo Wolfgang, São Paulo. Ed. Revista dos Tribunais, 2011.

SÉGUIN, Elida. Código Florestal e a Questão Urbana. Revista Brasileira de Direito Ambiental, ano 2, v. 8. São Paulo: Fiuza, out./dez. 103-119, 2006.

SILVA, José Afonso da. Direito ambiental constitucional. São Paulo: Malheiros editores, $5^{\text {a }}$ ed., 2004.

SILVA, José Afonso da. Direito Urbanístico Brasileiro. ERT, São Paulo: 1981.

SIRVINKAS, Luis Paulo. Manual de Direito Ambiental, $4^{\circ}$ ed. Atual. e ampl., São Paulo, Saraiva, 2006.

THOMÉ, Romeu. Manual de Direito Ambiental. Salvador: JusPodivm, 2012.

VAZ, Isabel. Direito Econômico das Propriedades. 2 ed. Rio de Janeiro: Forense, 1993. 